\title{
Potential and Problems of Small Medium Enterprise (SMEs) Coconut-Sugar: Case Study in Banyumas Regency, Central Java Indonesia
}

\author{
Suliyanto ${ }^{1}$, Agus Suroso ${ }^{1} \&$ Dian Purnomo Jati ${ }^{1}$ \\ ${ }^{1}$ Economics Faculty Jenderal Soedirman University-Indonesia, Indonesia \\ Correspondence: Suliyanto, Economics Faculty Jenderal Soedirman University, Indonesia. Tel: 62-812-272-6400. \\ E-mail: suli_yanto@yahoo.com
}

Received: November 23, 2012

Accepted: December 20, 2012 Online Published: January 15, 2013

doi:10.5539/ijbm.v8n3p18

URL: http://dx.doi.org/10.5539/ijbm.v8n3p18

\begin{abstract}
Coconut sugar or palm sugar is superior product in Banyumas regency, which supported by widespread of coconut tapping trees covering 5,157 ha and production of coconut sugar reach 57,400 tons per year, but welfare of coconut sugar entrepreneur are still relatively low. Therefore, it needs to be examined about the main problems of Small Medium Enterprises (SMEs) coconut sugar. This study used an exploratory approach as it aims to explore the potential and problems of SMEs coconut sugar. The study was conducted in any clusters SMEs coconut sugar, in Banyumas Regency. Source data from coconut sugar entrepreneurs and parties which related to the development of coconut sugar industry in Banyumas.

The analysis showed that the four major problems in the industrial sector are the production of coconut sugar, human resources, finance, and marketing. Program development should rely on these main problems, so the role of coconut sugar as superior product can improve the welfare of community businesses.
\end{abstract}

Keywords: Coconut sugar, Small Medium Enterprises (SMEs), potential and problem

\section{Introduction}

Small Medium Enterprises (SMEs) play a significant role in the business system of both developed and developing Countries (Ab-Rahman, 2012). Small industry is part of national industry that has the primary mission is employment and business opportunities, improving coconut sugar entrepreneur welfare, the provision of goods and services as well as various compositions both for the domestic market and overseas market. The majority firms worldwide are SMEs, and they play a significant role in economy. The attention in researching small businesses is rapidly growing. Over past three decades it has become popular among academics to focus investigation on small and medium sized organization (McLarty.et al., 2012). Tripathi and Siddiqui (2012) state that main reason to focus on the SME sector is that this entrepreneurship influences society and contributes to the economic development of the region where it is located. They influence the activities of all kinds of firms, but there are special problems that affect SMEs more than larger businesses (McLarty et al., 2012).

Banyumas Regency is an agricultural area that has considerable natural resources particularly in agricultural potential. Thus, mostly activities that conduct there in the form of industrial processing / use of natural resources and service industry. The food industry is run by people then become household industry which absorbs employment by using raw materials from surrounding area. Coconut sugar or palm sugar is a type of food processing industry communities that have the highest production values and produced by people in almost every district in Banyumas. The number of coconut sugar entrepreneur in Banyumas, there were 27,862 people spread over 217 coconut sugar entrepreneur groups in 23 districts (Bank Indonesia, Purwokerto, 2011).

Base on above description shows that Banyumas Regency has a high potential for the development of the sugar industry as superior product of local coconut. Currently, production activities be done in individuals and small-scale enterprise. Coconut sugar potential is not yet matched by the development of coconut sugar industry. Though the product is important as an input for many industries such as soy sauce, porridge, cake and others, but welfare of coconut sugar entrepreneur is still far from expectation. Therefore improve the quality of production and expand its sales market are should be done for reaching welfare of coconut sugar entrepreneur. Nowadays some institutions have tried to develop the coconut sugar processing business, such as the Regional Development 
Planning Board, Department of Industry, Trade and Cooperatives, Bank Indonesia, NGOs and others, but the results have not been optimal yet. This is because coaching is not comprehensive enough and not based on the real main problem. Therefore, research is needed to formulate a model of the development of coconut sugar in a comprehensive and applicable to be implemented. Model development should be based on the real problems which faced by coconut sugar entrepreneur so that the model could leverage coconut sugar sector as a superior product and a prosperous livelihood options for society.

Understanding of the issues and its potential are extremely important as the input for creating a master plan for development of coconut sugar industry. Thus, the question proposed in this research is "What are the problems and potentials of coconut sugar industry in Banyumas Regency? The results are expected to be utilized by the parties concerned, the Regional Planning Agency of Banyumas Regency, Department of Industry, Trade and Cooperatives, Bank Indonesia, and NGOs to synchronize their programs with the aim of developing a coconut sugar industry.

\section{Literature Review}

\subsection{SMEs Characteristics}

SMEs are defined against various criteria, such as different sectors, the number of workers employed, the volume of output or sales, the value of assets employed and even the use of energy (ILO 2003). In addition, the definitions of SME differ from one country to another, as they can be based on a nation's history and economic situation (Cunningham and Rowley, 2010).

Small businesses, usually defined as those with only a few or no employees, have been the backbone of ethnic business (Fong et al., 2012). There is no widely accepted statistical demarcation of a small firm. The number of employees might define a small firm (Verhees and Meulenberg, 2004). SMEs in Indonesia defines in three categories, an small enterprises as business that having annual sales fewer than Rp. 50 million, and having asset fewer than Rp. 300 million per year, medium enterprises as business that having volume annual sales between Rp. 50 until Rp.500 billion per year, and having asset between Rp. 300 million until 2,5 billion, medium entreprises as business that having volume of output or sales fewer than Rp. 50 billion, and having asset fewer than Rp. 10 billion per year, all categories are not including land and building (UU No. 20 tahun 2010).

Small- and medium-sized companies have importance role in socio-economic sector in some countries (Wolff and Pett 2006). The majority of the firms worldwide are categorized as SMEs. They are important in creating jobs and promoting the overall growth of the economy, for example, by bringing innovations to the markets (Reijonen et al., 2012). SMEs have long been believed to be important in supporting economics development within a country (Mazzarol, Volery, Doss, \& Thein, 1999. One of the important roles of SMEs in this context includes poverty alleviation through job creation. Small and Medium Enterprises have important role in Indonesia about 99 percent of the workforce is working in SMEs and contribution of SMEs on Gross Domestic Product (GDP) more than 55 percent (Suselo, 2012). In spite of the great importance of SMEs in economic activity, most such firms do not participate actively in international business (Oritz \& Lombardo, 2009).

A small firm is a firm that is run and is controlled under the direct supervision of the owner. A farm is a case in point. Actually, small firms are a subset of SMEs (Verhees \& Meulenberg, 2004). They have highly centralized structures with the chief executive officers (CEOs) making most of the critical decisions (Mintzberg 1979). They tend to employ generalists rather than specialists (Blili \& Raymond 1993). They lack the resources of larger firms and thus are highly susceptible to shortrange planning (Welsh and White 1981). Most of them experience resource poverty in the areas of finance, IT/IS skills, time and planning (AI-Qirim 2003). SMEs are characteristically highly diverse and heterogeneous; their traditional dominance is in a few industrial sub-sectors such as food, textiles and light engineering and wood, cane and bamboo products. Normally, SMEs do not have many customers and concern only for a limited business area (Rahman, 2012).

Small firms are no bureaucratic and more flexible than large firms; the owner is the decision-maker (Nooteboom 1994). Information systems in small firms relatively are simple (Verhees and Meulenberg, 2004). Information is based on secondary data or on direct, formal and informal, external contacts of the owner (Smeltzer, Fann, and Nikolaisen 1988). Small firms' limited access to finance for venture capital is a hotly debated barrier to innovation (Carson et al., 1995).

SMEs are closer to customers and able to respond to their needs quickly and flexibly, they have less organizational bureaucracy and thus they are able to disseminate customer information quickly and with fewer modifications, and finally, due to their more informal nature, they can implement marketing plans quickly (Keskin, 2006). 


\subsection{SMEs Problem}

Research done by Khan and Rocha (1982) aimed to identify and analyzes some recurring problems experienced by small businesses. Khan and Rocha (1982) identified four major problems areas, namely marketing, accounting, inventory control, and cash flow management. Later study done by Franklin and Goodwin (1983) characterize three types of problems that exist in small scale business. Those three types are: 1) external factors, those factors usually beyond the direct control of management, 2) internal factors, those factors that management deals with day to day and over which it has degree of control, 3) financial, a combination of internal financial factors and external capital markets. Further they suggest that of the top ten problems, external factors appear to be the most important.

SMEs usually cannot afford to hire qualified auditors, which makes their financial reports suspicious and creates information asymmetries between insiders and outsiders. Moreover, their information asymmetries may become even worse during recessionary periods. Despite their importance, SMEs have difficulty securing financing from banks (Shen et al., 2012). Large banks are generally not interested in serving SMEs (Shen, et al., 2012). Berger and Udell (2006) argue that large banks are not disadvantaged in small business finance because they can deliver funds to SMEs through various lending technologies, which can overcome the problems of informational opacity (Shen et al., 2012). SMEs are less able to replace bank financing with other sources of external financing when facing financial constraints (Shen et al., 2012). Most of SMEs have limited resources so the reduction of operating costs is a main concern (Bennett, Graham, and Bratton, 1999).

SMEs usually lack the amount of slack resources and administrative systems that help larger companies in their decision-making processes and, consequently, SMEs have to rely more on the abilities of their managers (Lubatkin, Ling and Veiga, 2006). The specific resources and capabilities of small firms have consequences for market orientation as defined by Kohli and Jaworski (1990). In small firms, resources for market intelligence generation are scarce, and there is no room for a marketing specialist (Verhess and Maulenberg, 2004).

According to Urata (2000) the problems faced by Small and Medium Enterprises (SMEs) can be categorized into two: financial problem and non-financial problem (organizational management). Problems which included in the financial problems are: 1). Lack of compliance between providing funds and funds which is can be accessed by SMEs. 2). No systematic approach in SMEs funding. 3). High transaction costs, it caused by credit procedures which are quite complicated so it took a lot of time while the disbursed loan amount is very small. 4). Lack of access to formal sources of funds, whether caused by unavailability of bank or inadequate information. 5). High of interest loans for investment and working capital. 6). SMEs are not bankable, either due to lack of transparent financial management and a lack of managerial and financial capabilities.

While the problems that are included in the non-financial issues (organizational management) are: 1) Lack of knowledge on the technology of production and quality control due to the lack of opportunity to keep abreast of technology and lack of education and training. 2) Lack of marketing knowledge, which is caused by lack of information about market condition, and limited SMEs to provide products / services in accordance with the expectation of market. 3) Limitations of human resources (HR) 4) Lack to understanding about accounting and finance.

\subsection{Coconut-Sugar SMEs in Indonesia}

Indonesia is the largest coconut sugar producer in the world, with a production capacity of 120,000 tons per year, followed by Thailand with a production capacity of 15,000 tons per year, followed by India and the Philippines. Banyumas region is an area of considerable potential for the development of coconut sugar. The raw material is coconut sap sugar derived from coconut trees. The potential of coconut sugar in Indonesia is also supported by the areal extent of oil that reached 3.707 million hectares, followed by the Philippine area of 3,077 thousand hectares, India 1908 thousand hectares, Sri Lanka 442 thousand ha, 372 ha Thailand, and other countries covering 2,398 thousand ha (Mustaufik, 2010). A total of $70 \%$ of the national supply of coconut sugar comes from Banyumas Residency.

According to Sukiman, (2007), coconut sugar agro-industry development in Indonesia, coconut sugar entrepreneur had some problems as follows: 1). Unstable price fluctuations caused by the poor quality of produced coconut sugar, 2). Weather factors that can cause disease in coconut trees which causing low quality on coconut sugar, 3). Lack of capital for the maintenance of a coconut tree, because the income from the sale of coconut sugar only for their daily needs. 4). Poor of marketing and distribution system such as monopoly marketing system, and 5). Unfair pricing determination by middle seller coconut sugar.

Supomo (2007), states that most of coconut sugar entrepreneur produce low quality coconut sugar, not 
uniformity, limited access to markets, getting the value chain that are low in coconut sugar commodities business processes are generally still low, traditional, yet have an entrepreneurial spirit, so that it is causing thought to not improve the quality of production, and expand market sales of coconut sugar production. The living condition of the coconut sugar entrepreneur is terrible. They are hard to break away from broker. There is no organization that protects coconut sugar entrepreneur from accident and get welfare.

\section{Method}

The population in this study are all coconut sugar entrepreneurs and parties which related to the development of coconut sugar industry in Banyumas. The sample size for coconut sugar entrepreneur as 151, with proportional random sampling technique while for not coconut sugar entrepreneur it is used purposive sampling method.

This research used triangulation method as data collection methods which is consist of observation, questionnaires, documentation, in-depth interviews and a Focus Group Discussion (FGD) with coconut sugar entrepreneur, government Industry, Trade and Cooperatives office, Forum of Economic Development and Employment Promotion (FEDEP) Banyumas, government Agriculture and Plantation office, Bank Indonesia (BI) Purwokerto, community leaders or observers of coconut sugar and other parties involved in coconut sugar program development Banyumas. Data analysis used qualitative analysis and descriptive statistics.

\section{Discussions}

\subsection{Potential of SMEs Coconut Sugar in Banyumas Regency}

Banyumas region is an area with huge potential for development of coconut sugar. Based on data from Industry, Trade and Cooperatives Department in Banyumas, in 2012 area of coconut plantations in Banyumas is about 17,814 ha recorded by the number of plants a tree as $1,746,871$ trees. Plantation area where used as the coconut tap is 5157 ha with 460,980 as the number of plants a tree. It can produce approximately 57,400 coconut sugar tonnes / year. The number of coconut sugar entrepreneur in Banyumas, there were 26,265 people spread in 2298 by coconut sugar entrepreneur groups in 23 districts, with Cilongok District, Kebasen District, Gumelar District, Somagede District and Purwojati District is the highest potential area.

The quality of coconut sugar which produced from Banyumas is the best coconut sugar and has its own identity when compared to other coconut sugar. This opinion is proven from its taste, smell, shape preferred by many customers from outside area. Sugar from Banyumas is sweeter and has a lower salt content that others, because coconut trees in Banyumas is generally far from the sea. As in other areas of coconut sugar production by micro and small enterprises, with simple equipment and technology, and therefore the resulting quality is often inconsistent. An overview of the potential of coconut sugar in Banyumas district can be seen from the following table:

Table 1. Coconut sugar potential in Banyumas Regency

\begin{tabular}{llcc}
\hline No & Information & Volume & Unit \\
\hline 1 & The proportion of coconut sugar smes to total SMEs in & 70 & Percent \\
& Banyumas & & Head of Family \\
2 & Number of coconut sugar entrepreneur & 26,265 & Group \\
3 & Number of entrepreneur groups & 298 & Tons / year \\
4 & Coconut sugar production & 57,400 & $\mathrm{Kg} / \mathrm{Ha}$ \\
5 & The average production & 9,191 & $\mathrm{Ha}$ \\
6 & Coconut tree land & 17,814 & $\mathrm{Ha}$ \\
7 & Coconut tapping land & 5,157 & Tree \\
8 & Number of coconut trees & $1,746,871$ & Tree \\
9 & Number of coconut tapping & 460,980 &
\end{tabular}

Source: Bank Indonesia, Purwokerto 2011. 


\subsection{Production Problems}

Coconut sugar processing entrepreneur dominated by men, it is reasonable since the production of coconut sugar requires physical strength. From the total respondents of 151 coconut sugar entrepreneurs, the number of men are 147 and 4 are women. Considering from education level, mostly coconut sugar entrepreneur in Banyumas only attained primary school education (SD). The coconut sugar entrepreneur in Banyumas Regency have an average production capacity per day up to $6 \mathrm{~kg}$. Every day coconut sugar entrepreneur usually have 15 trees to be tapp. The production of coconut sugar is in the form of bulk. Another form produced but still on a small scale is granulated coconut sugar, for liquid coconut sugar has not been produced by coconut sugar entrepreneur in Banyumas.

The average number of trees that can be tapp by the coconut sugar entrepreneur are 26 coconut trees. Meanwhile, the total amounts that can be tapp are 120 coconut trees. Considering from the status of ownership, $48 \%$ of the trees which is partly self-owned and partly owned by others. The next portion, $31 \%$ are self-owned coconut trees and $21 \%$ is owned by someone else.

For those who tap the coconut trees which belonging to someone else, there are some systems that are used to divide the gains from it. In general, coconut sugar entrepreneur are implementing an equitable distribution system, which is $50 \%$ of the trees to the right of the owner of the tree and the rest more that $50 \%$ for the sugar tapper. Distribution of coconut tapping results given to the owner of the tree coconut sugar entrepreneur still in the form of coconut sap with a name based on the period giving the market in terms of Java, namely Pahing, Wage, Legi, Pon, and Kliwon. Aside of five days period, there another system of distribution such as two-day period and rental system in the form of coconut sugar to the owner of the tree.

Based on the number of tapping coconut trees, the average number of coconut sugar production produced by coconut sugar entrepreneur are $6 \mathrm{~kg}$ /day. Total production is greatly influenced by his supporters. If things are being supported to produce then there coconut sugar entrepreneur reaches $15 \mathrm{~kg}$ per day, but this is supported also by the number of trees.

Production capabilities of each coconut trees to produce coconut sap per day are generally not equal. Quality of sap itself also vary, both between trees or between time as the amount of sap production. Thus, it is impact the quality of coconut sugar produced.

There is different treatment from every entrepreneur in the processing of coconut sap into sugar. First, in terms of filtering the sap before it is processed into coconut sugar. For those who do not pre-screen, it is because it will enter the factory and thawed again, so they feel no need to do the filtering at the plant will be a screening process. Then in the term of "laru" (in Java) variation. Laru function to preserve the sap from becoming sour/stale and helps hardening of coconut sugar. Domination laru used is mixed of lime solution and mangos teen skin, its produces coconut sugars with higher quality. However, there are still quite a lot of coconut sugar entrepreneur who use sodium metabisulphite as laru which is not good if consumed by humans. Besides using mixed of lime solution and mangos teen skin, some coconut sugar entrepreneur using laru form mixed of lime solution and jackfruit tree chips, or betel leaves. things which still need to be developed from the coconut sugar entrepreneurs that there are few coconut sugar entrepreneur who still use sodium metabisulphite laru so that coconut sugar production does not failed and also coconut sugar entrepreneur who still likes to mix them with shavings of coconut sugar / cassava to enlarge heavy coconut sugar is produced. It continued in the long term if the result is not good, because it would lower consumers buying interest due to the poor quality of coconut sugar.

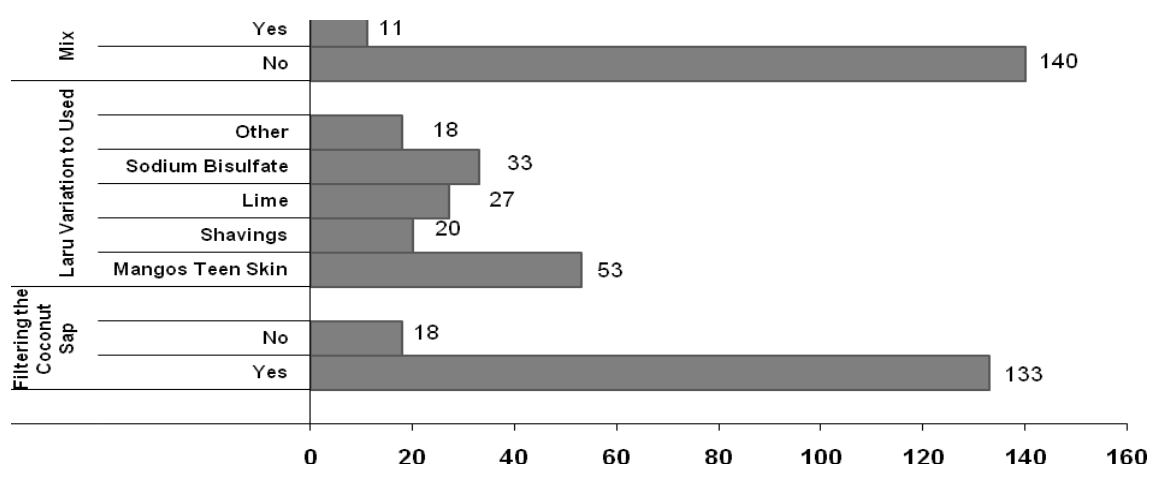

Figure 1. Coconut sugar entrepreneur treatment toward coconut sap 
About the quality problems of resulting coconut sugar, a lot of coconut sugar entrepreneurs said it was difficult for reating equality toward its quality. According coconut sugar entrepreneur, it is triggered by unsupported weather / season. It also encourages coconut sugar entrepreneur to use laru from chemicals (sodium metabisulphite) as a solution. This behavior still become a huge attention to be educated by parties which concern indeed.

This finding is in line with earlier studies in both in manufacturing and service sector (see Khamalah \& Lingaraj, 2003; Khamalah \& Lingaraj, 2007). Both writer conclude that there much less serious about implementing quality improvement program in small organizations (businesses). In coconut sugar setting, the inconsistency of coconut sugar entrepreneurs in implementing quality program is rooted from the short vision of business; most of them cannot see the long impact of keeping superior product quality.

\subsection{Human Resources Problems}

The coconut sugar entrepreneur in Banyumas Regency takes an average of 2 people labor in its production operations. Seeing from the source, almost all are empowered workforce sourced from the family, which reached $99 \%$.

Meanwhile for the methods / systems of remuneration made by the coconut sugar entrepreneur were using a system based on the quantity of output produced by a worker, and the daily system.

Thing that need to be concerned about employment is that $80 \%$ coconut sugar entrepreneur declared that he does not have a successor business. This is very worrying, especially in terms of the regeneration of the next/future. The dominant reason appears is little intention to be a coconut sugar entrepreneur of coconut sugar like their parents, since they considering that pursuing a job in coconut sugar production is not promising enough for their future.

For increasing the quality and productivity, it is important to conduct training for business actors continuously. Commonly coconut sugar entrepreneurs less in training. Almost $53 \%$ of respondents said that in their area there is no specific training on quality improvement efforts in the field of business coconut sugar. This situation should be of particular production.

\subsection{Financial Problems}

The coconut sugar entrepreneur of coconut sugar in Banyumas Regency still need guidance in terms of the financial management of the business because it is still poor in the term management of finances. Many as $96 \%$ coconut sugar entrepreneur states have not made financial records. Slightly different, as much as $95 \%$ coconut sugar entrepreneur stated that they did not do the separation between business finance and personal finance.

The reluctance of the coconut sugar entrepreneur is to do business financial records since assuming the financial records of business is not important activity. Reasons include lack of personnel who records it, doesn't have technical knowledge about financial business, the amount of capital business is still small, the results of sales efforts directly used for daily needs, and activity records is a cumbersome job.

The absence of financial administration affects in the absence of separation between business finance and personal finances. The underlying reason is usually because the business directly used for daily needs, the results of sales efforts directly used for daily needs, and activity records is a cumbersome job, and does not have time to record the results of operations due to sales efforts directly used for other things.

On the issue of capital, $38 \%$ of respondents state having this problem which is shown in the following figure.

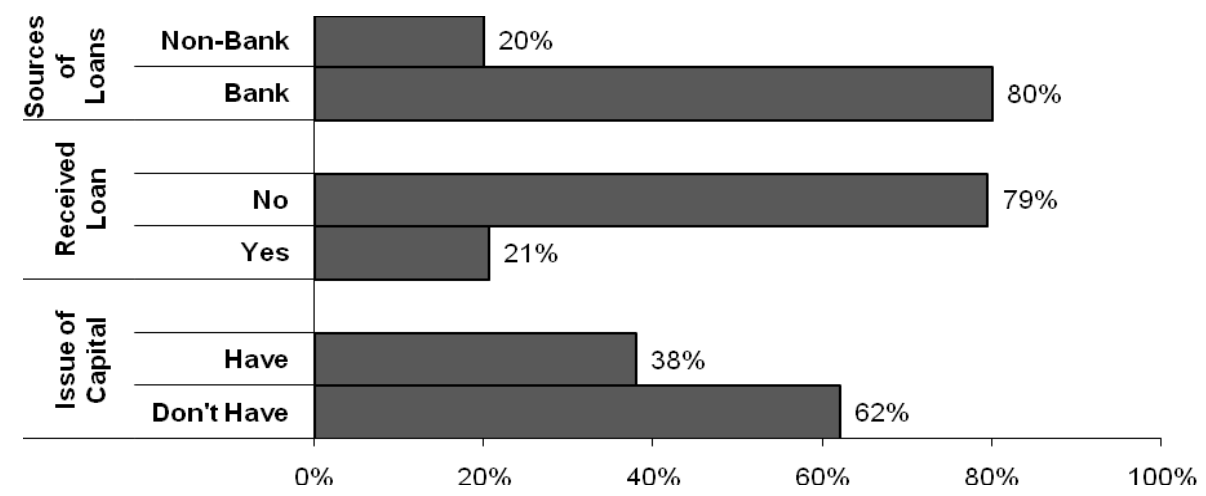

Figure 2. Tapper capital 
The capital problems which encountered by coconut sugar entrepreneur is to fulfill the needs of equipment / tools in the operations of coconut sugar production. Aside because of the damage that needs to be repaired, it also for increasing the volume of production.

Then, from the existing number of respondents, $79 \%$ stated that their coconut sugar entrepreneur have never received loans for their businesses coconut sugar. The reason why they not received credit due to the coconut sugar entrepreneur did not apply for credit to financial institutions. Factors that limit their access to financial institutions is vary, such as fear toward the risk of higher interest rates, complex procedures, does not have a guarantee, it's basically not interested, or because they do not require credit for his efforts.

\subsection{Marketing Problems}

Demand of coconut sugar is greater than the number of production. Demand of coconut sugar comes from sauce factory, a bakery, houses purposes through traditional markets and supermarkets as well as export demand. The problem of marketing is a price that is unstable and very easily manipulated by the middle seller. Another issue in marketing is a quality product that is not standard, so that it hard to pass export markets, besides that there are many coconut sugar entrepreneur who use preservative sodium metabisulphite that can harm our health.

Marketing distribution of coconut sugar using multiple intermediaries, such as collectors and agents, very few coconut sugar entrepreneur who have direct access to the market. The process of determining the price is usually determined by the mediator, so that opportunistic behavior that benefits only one party (the mediator) potentially happen at this stage. Just trust factor is involved in controlling this transaction. Mostly coconut sugar entrepreneur do not use promotion and product packaging on marketing or selling their products. This is caused by the transaction agreements that have taken between the coconut sugar entrepreneur and collectors, so that the coconut sugar entrepreneur feel that it is not necessary for doing promotion and packaging of the product in particular.

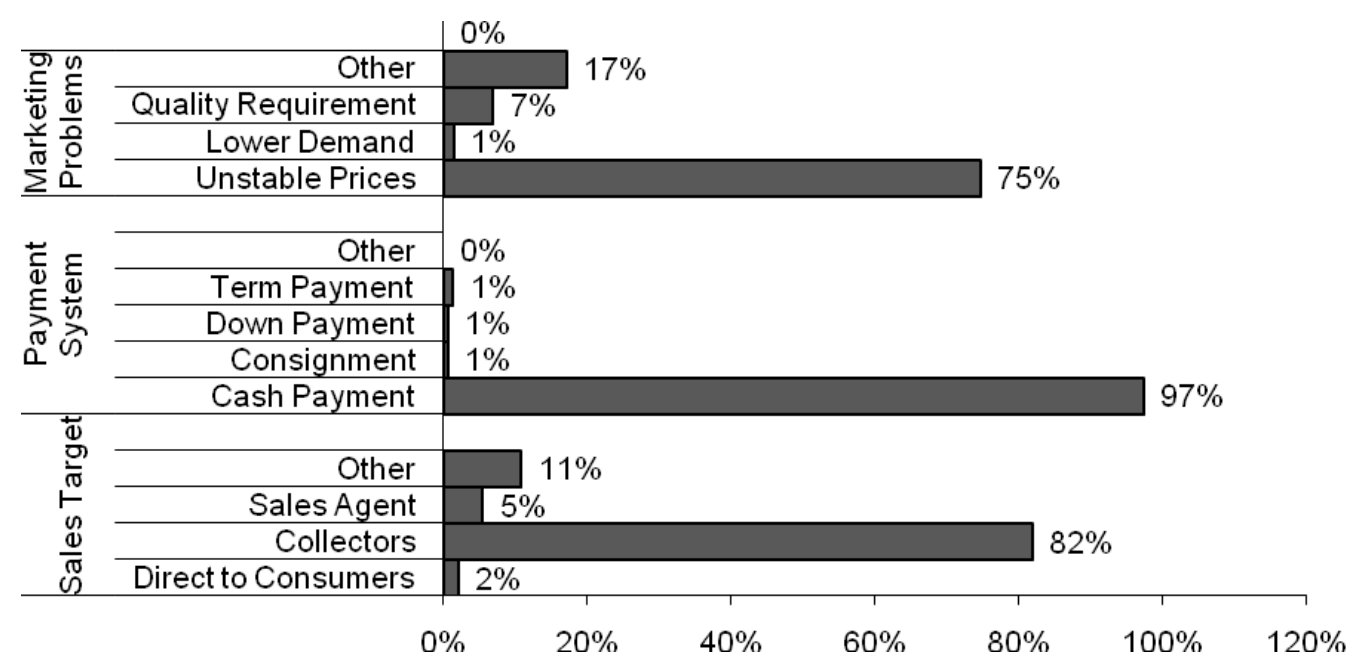

Figure 3. Description of coconut sugar sales activity

\section{Conclusions and Future Research Suggestions}

Coconut sugar products have huge potential to be developed as a superior product locally. Supported by suitable highland topography with plant area of coconut tapping land covering 5,157 ha and it able to produce coconut sugar as much as 57,400 tons per year and is the largest plantation crop production in Java, large population centers of production at the site, it appears that coconut sugar production capacity still open to be improved. Coconut sugar sector development efforts should rely on a variety of factors were identified as the root of the problem in the sector, the problems in the field of production is still vary quality, low human resource capacity, finance and financial administration capitalization, and marketing. Sharpening programs and activities based on the description of the problem will have a higher probability to be success than a lot of programs but partially implemented and without institutional coordination.

This study leads to the next research question. Therefore future research could be conducted to determine the impact of the effectiveness of programs that are designed based on the results of this research through field 
experiments, particularly on the aspects of production and capacity building. Future research will also need to develop a holistic model of coconut sugar sector development by involving the various stakeholders.

\section{References}

Ab Rahman, Mohd Nizam. (2012). The Effective Implementation of Global Supply Chain Management in Small to Medium-sized Companies in Malaysia: An Empirical Study. International Journal of Management, 29(3), 274-287.

AI-Qirim, N. A. Y. (2003). The strategic outsourcing decision of IT and ecommerce: the case of small business in New Zealand. Journal of Information Technology Cases and Application, 5(3), 32-56.

Bank Indonesia Purwokerto. (2011). Laporan Pengembangan Gula Kelapa Di Desa Karanggintung, Kemranjen, Kabupaten Banyumas.

Bennett, R. J., Graham, D. J., \& Bratton, W. (1999). The Location and Concentration of Businesses in Britain: Business Clusters, Business Services, Market Coverage and Local Economic Development. Transactions of the Institute of British Geographers, 24, 393-420. http://dx.doi.org/10.1111/j.0020-2754.1999.00393.x

Berger, A. N., \& Black, L. K. (2006). A More Complete Conceptual Framework for SME Finance. Journal of Banking and Finance, 30(11), 2945-2966. http://dx.doi.org/10.1016/j.jbankfin.2006.05.008

Blili, S., \& Raymond, L. (1993). Information technology: threats and opportunism from smalland medium-sized enterprises. International Journal of Information Management, 13(6), 439-448. http://dx.doi.org/10.1016/0268-4012(93)90060-H

Cunningham, Li, X., \& Rowley, Chris. (2010). Small and medium-sized enterprises in China: a literature review, human resource management and suggestions for further research. Asia Pacific Business Review, 16(3), 319-337. http://dx.doi.org/10.1080/13602380903115948

Fong, E, Chen, W., \& Luk, C. (2012). A Study of Locational Distribution of Small and Large Ethnic Businesses in a Multiethnic City: Chinese in Toronto, Canada. Journal of Small Business Management, 50(4), 678-698. http://dx.doi.org/10.1111/j.1540-627X.2012.00371.x

Franklin, S. G., \& Goodwin, J. S. (1983). Problems of Small Business and Sources of Assistance: A Survey. Journal of Small Business Management.

ILO Report. (2003). Retrieved from hattp://www.ilo.org

Keskin, H. (2006). Market Orientation, Learning Orientation, and Innovation Capabilities in SMEs. An Extended Model. European Journal of Innovation Management, 9, 396-417. http://dx.doi.org/10.1108/14601060610707849

Khamalah, J. N., \& Lingaraj, B. P. (2003). A Study of Quality Management in Small Organizations Providing Services Directed At People. Journal of Business \& Economic Research, 1, 61-68.

Khamalah, J. N., \& Lingaraj, B. P. (2007). TQM in The Service Sector: A Survey of the Small Businesses. Total Quality Management, 18(9), 973-982. http://dx.doi.org/10.1080/14783360701592059

Khan, M. R., \& Rocha, J. R. (1982). Recurring Managerial Problems in Small Business. American Journal of Small Business, 1 .

Kohli, A., \& Jaworski, B. (1990). Market Orientation: The Construct, Research Proposition and Managerial Implication. Journal of Marketing, 54, 1-18. http://dx.doi.org/10.2307/1251866

Lubatkin, M. H., Ling, Y., \& Veiga, J. F. (2006). Ambidexterity and performance in small-to medium-sized firms: the pivotal role of top management team behavioral integration. Journal of Management, 32, 646-672. http://dx.doi.org/10.1177/0149206306290712

Mazzarol, T., Volery, T., Doss, N., \& Thein, V. (1999). Factors which influence small Business start-ups. International Journal of Entrepreneurial Behaviour and Research, 5(2), 48-63. http://dx.doi.org/10.1108/13552559910274499

McLarty, Roy, Pichanic, Mikulas, \& Srpova, Jitka. (2012). Factors Influencing the Performance of Small to Medium-Sized Enterprises: An Empirical Study in the Czech Republic. International Journal of Management, 29(3), 36-47.

Mintzberg, H. (1979). The structuring of organizations. Englewood Cliffs, NJ: Prentice-Hall.

Mustaufik. (2010). Pengembangan Agroindusti Gula Kelapa Kristal Sebagai Sumber Gula Alternatif untuk 
Mengurangi Ketergantungan Dunia Terhadap Gula tebu. Lembaga Penelitian dan Pengabdian Kepada Masyarakat Unsoed.

Nurul Indarti, \& Marja Langenberg. (2005). A Study of Factors Affecting Business Success Among SMEs: Empirical Evidences from Indonesia. Asian Social Science, 7(5).

Ortiz, R. F., \& Lombardo, G. F. (2009). Influence of the capacities of top management on the internationalization of SMEs. Entrepreneurship \& Regional Development, 21(2), 131-154. http://dx.doi.org/10.1080/08985620802176104

Reijonen, H. T. T., Laukkanen, R., \& Tuominen, S. (2012). Are growing SMEs more market-oriented and brand-oriented? Journal of Small Business Management, 50(4), 699-716. http://dx.doi.org/10.1111/j.1540-627X.2012.00372.x

Shen, CH, Chu, H., \& Chun Wang. (2012). Who Furls the Umbrella on Rainy Days? The Role of Bank Ownership Type and Bank Size in SME Lending Emerging Markets. Finance \& Trade, 48, 184-199. http://dx.doi.org/10.2753/REE1540-496X48S211

Smeltzer, L. R., Fann, G. L., \& Nikolaisen, V. N. (1988). Environmental Scanning Practices in Small Business. Journal of Small Business Management, 26(3), 55-62.

Sukiman, Dumasari, \& Dan Sulistyani Budiningsih. (2007). Analisis Kelayakan Usaha Agroindustri Gula Kelapa Di Desa Panerusan Kulon Kecamatan Susukan Kabupaten Banjarnegara.

Supomo. (2007). Meningkatkan Kesejahteraan Pengrajin Gula Kelapa di Wilayah Kabupaten Purbalingga. Jurnal Ekonomi Pembangunan, 12(2), 149-162.

Suselo, Sri Liani. (2012). Peranan Bank Indonesia dalam Pengembangan Usaha Mikro Kecil dan Menengah. National Seminar and Call for Papers Sustainable Competitive Advantage-2. Management Majoring, Economics Faculty Jenderal Soedirman University.

Tripathi, S. N., \& Siddiqui, M. H. (2012). Marketing of SME Products: A 'Relationship' Approach. Journal of Management, 41(2), 76-106.

Urata, Shujoro. (2000). Policy Recommendation for SME Promotion in the Republic of Indonesia. Finance and Industry.

Verhess Frans, J. H. M., \& Meulenberg Matthew, T. G. (2004). Market Orientation, Innovativeness, Product Innovation, and Performance in Small Firms.

Welsh, J. A., \& White, J. F. (1981). A small business is not a little big business. Harvard Business Review, 59(4), 18-32.

Wolff, J. A., \& Pett, T. L. (2006). Small-firm performance: Modeling the role of product and process improvements. Journal of Small Business Management, 44, 268-84. http://dx.doi.org/10.1111/j.1540-627X.2006.00167.x 